\title{
Fiscal Deficit of Rajasthan: Trends, Cycles and Seasonal Variation
}

\author{
Dr. Debesh Bhowmik \\ (Former Principal and associated with Lincoln University College,Malaysia) \\ Life member: (Indian Economic Association, The Indian Econometric Society, Bengal Economic Association, \\ Economic Association of Bihar) \\ Author: (of 10 books and Editor of 2 volumes and co-editor of 2 volumes, and author of more than 180 published \\ papers in journals and edited volumes) \\ Residence: P.O.+Village-Pritinagar, District-Nadia, West Bengal, 741247 \\ https://orcid.org/0000-0002-0293-1066 \\ Scopus Author ID:55447913300 \\ Web of science researcher ID=AAW-8233-2020
}

\begin{abstract}
The paper has explored the smooth cyclical trend,cycles and seasonal patterns of fiscal deficit in gross and in per cent of net state domestic product of Rajasthan in current prices during 1990-91-2018-19 by applying Hamilton regression filter model(2018) which was also passed through $\operatorname{ARIMA}(p, d, q)$ forecasting model for 2030 and was also verified by heteroscedasticity test.Both the fiscal deficits in gross and in per cent of NSDP showed many peaks and troughs in cyclical patterns but only one peak and trough were found in the smooth cyclical trends and the inverse $\mathbf{v}$ shaped seasonal fluctuations were visible with no heteroscedasticity problems.Their ARIMA forecast models for 2030 are convergent,significant and move towards equilibrium.
\end{abstract}

Keywords:- Gross Fiscal Deficit, Gross Fiscal Deficit \% Of NSDP, Cyclical Trend, Cycles, Seasonal Variation, Hamilton Filter, ARIMA $(p, d, q)$

JEL Classification codes-C20,C32,E30, H62, H68, H70.

\section{INTRODUCTION}

Rajasthan is the largest state in terms of area (342.24 thousand sq. $\mathrm{km}$ ) but ranks 8th position in terms of population. Rajasthan's population density is 201 compared to 382 for India in 2011. The state is being ranked as the 10th least developed states in India. In terms of major socioeconomic indicators Rajasthan is far behind the national average. Poverty scenario of Rajasthan is very acute although poverty rate has been declining from $34.470 \%$ in 2004-05 to $14.71 \%$ in 2011-12. This state contributes $3 \%$ of GDP of India and scores low human development indicators. The net state domestic product at current prices of Rajasthan has been catapulting by $13.70 \%$ per year significantly from 1990-91 to 2018-19, on the other hand, net state domestic product per capita at current prices has been stipulating at the rate of $11.69 \%$ per year significant during the same period. It implies that the state Rajasthan is growing very fast.
The relationship between fiscal deficit and growth signifies different implications. Adam and Bevan (2005) examined the relationship between fiscal deficit and growth for 45 countries during 1970 - 1999 taking panel data and found that values of deficit less than or equal to $1.5 \%$ of GDP were found to be growth enhancing whereas deficits above that threshold level were found to be growth deteriorating. Mundle,Bhanumurthy and Das (2011) examined the macroeconomic implications of alternative fiscal strategies in fiscal consolidation maintaining high GDP growth rate reducing zero revenue deficit while state and center's fiscal deficit is of $6 \%$ of GDP.This provides the space for substantial government capital expenditure, which translates to a significant public investment program. This in turn leads to high overall investment directly and indirectly, via the crowding in effect on private investment, which drives the high GDP growth. The exercise has also tested the robustness of this strategy under two alternative scenarios of higher and lower advanced country growth compared to the base case.

Taylor et al (2012) verified the relation betweenfiscal deficit, debt and growth in US economy taking quarterly data from 1961 to 2011, and found that primary fiscal deficit has a significant positive effect on growth and higher debt affects growth adversely but causality result proved that a higher debt-GDP ratio is the consequence but not the cause of low growth. The total expenditure had a positive relation while tax revenue moved in a reverse direction with GDP. The authors strongly argue that higher fiscal deficit stimulates the economy during recession. Anantha Ramu and Gayithri (2016) examined on India's data by VECM taking data from 1980-81 to 2012-13 and found that a $1 \%$ change in fiscal deficit positively changes the GDP by $0.77 \%$ and a $1 \%$ increase in revenue deficit reduces GDP by $0.02 \%$. This result supports the 'Golden Rule' that if the deficit amount is used for capital expenditure purposes it significantly affects growth. 
But, in Rajasthan, one per cent increase in gross fiscal deficit per year led to 0.91 per cent increase in NSDP at current prices from 1990-91 to 2018-19 which is significant at $1 \%$ level but this relation suffers from autocorrelation problem and it is highly unstable during 1999-00-2010-11 with respect to CUSUM of squares stability test. Therefore, the relationship is not valid in all times and in any country or state. Even, there is no cointegration between gross fiscal deficit and net state domestic product of Rajasthan during the said period.

In this context, author endeavours to examine the nature and patterns of trends, cyclical fluctuation and seasonal variation of gross fiscal deficit and gross fiscal deficit as per cent of net state domestic product at current prices of Rajasthan from 1990-91 to 2018-19 with the help of econometric analysis.

\section{LITERATURE REVIEW}

Rajaraman, Mathur, and Majumder (2005) examined in their report that the TFC felt the need for fiscal correction where deficit in both the fields required for counter-cyclical flexibility which is urgently needed in the situation of severe agricultural cycles. The report framed three import scenarios for fiscal correction for 2005-2010. The State Strictly follows the Enacted FRBM in the first scenario and then Adds the further constraint of the absolute fiscal deficit gap of 2004-05 to Scenario I and finally the State follows the Fiscal Deficit Path for TFC Conformity and the revenue deficit Path for Full Debt Write-Off. Restructuring the Finances of the State should examines ways to improve own revenue collections both at state and local levels, funding road development, and examines a new 50:50 joint venture set up by the Government of Rajasthan with the Infrastructure and Leasing Finance Service Ltd, and recommended for improving the financial performance of the PSUs and power sector.

Centre for Budget and Governance Accountability(2011) in collaboration of UNICEF,prepared a special report on spending on children of Rajasthan for improvement in health,education, family welfare, water and sanitation, housing and so forth and allocated sector-wise funds for development including social sector and social services and unpacking four child centered national flagship programs (SSA, RCH, ICDS and TSC) during 1993-94 2009-10.The report found that Rajasthan has made significant progress over the past decade in improving its human development outcomes; but gender gaps persist, particularly in education.Segal and Sen (2011) studied that fiscal challenges of Rajasthan include sustaining growth in its own share of tax revenues and creating the fiscal space for development pending without considerably adding to public debt. Authors suggested policy of poverty alleviation, infrastructure development, rural development,increase in social sector expenditure with stepping up tax revenues.

Singh and Mahamallik(2014) stated in the report that the fiscal deficit of Rajasthan has been improving but the rate of improvement is volatile in nature and change is very slow. The state has been implementing FRBM Act is to reduce the revenue deficit to zero and fiscal deficit to less than $3 \%$ of GSDP. It is fact that the significant rate of growth of revenue expenditure in Rajasthan after a point of time could not be compensated by the rate of growth of revenue receipt in all the years. No doubt the per capita fiscal deficit remained negative but did show improvement gradually. Rajasthan has been able to reduce the revenue deficit and generate revenue surpluses to finance for investment. As a result, income could flow into the economy through multiplier effect which in turn led to the reduction of fiscal deficit. The policy of reduction of the Debt -GSDP ratio to raise the level of GSDP as well as reducing the proportion of loans is necessary.

Kaur(2017-2018) examined that there exists a longrun relationship between fiscal deficit,money supply,exchange rate volatility and inflation in India during 1970-71-2014-15 but the short run causality does not support the fiscal deficit inflation nexus.

Ashoke Gehlot announced that estimated revenue receipts in the budget of Rajasthan were Rs 1,73,404.42 crore, estimated revenue expenditure $1,85,750.03$ crore and estimated revenue deficit Rs 12,345.61 crore, whereas the estimated fiscal deficit stood at Rs 33,922.77 crore, which is 2.99 per cent of the gross state domestic product. In the agriculture sector, the chief minister announced to increase the area under date farming to 1,500 hectares in the next four years, and made a provision of Rs 91 crore for microirrigation facility. He also announced to exempt transfer of properties by sick MSMEs (micro, small and medium enterprises) from stamp duty. To give relief to the real estate sector, he proposed to decrease DLC rates by 10 per cent and increase stamp duty by 1 per cent. (PTI,2020,February 20).

\section{METHODOLOGY AND SOURCE OF DATA}

The non-linear trend line was estimated through semi$\log$ regression model. The forecast linear trend model was found by using Cochrane and Orcutt model(1949). The structural breaks were found by applying Bai-Perron model(2003).Decomposition of trend, cycles and seasonal variation was found by using the Hamilton filter model(2018).Cleveland et al.(1990) model was applied to Hamilton residual to get all decompositions under STL method. Even, Box and Jenkins (1970) methodology was used to fit $\operatorname{ARIMA}(\mathrm{p}, \mathrm{d}, \mathrm{q})$ model in the Hamilton filter residual.

Here the Hamilton (2018) regression filter is given below.

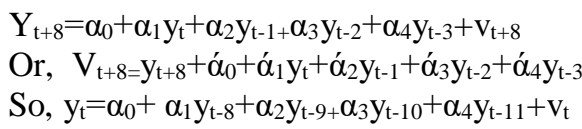

Therefore, $\mathrm{V}_{\mathrm{t}}=$ where $\alpha_{i}$ are estimated. 
$\mathrm{V}_{\mathrm{t}+\mathrm{h}}=\mathrm{y}_{\mathrm{t}+\mathrm{h}}-\mathrm{y}_{\mathrm{t}}$ is the difference i.e. how the series changes over $\mathrm{h}$ periods. For $\mathrm{h}=8$, the filter $1-\mathrm{L}^{\mathrm{h}}$ wipes out any cycle with frequencies exactly one year and thus taking out both long run trend as well as any strictly seasonal components.

It also applies random walk: $\mathrm{y}_{\mathrm{t}}=\mathrm{y}_{\mathrm{t}-1-\varepsilon_{\mathrm{t}}}$ where $\mathrm{d}=1$ and $\omega_{\mathrm{t}}^{\mathrm{h}}=\varepsilon_{\mathrm{t}+\mathrm{h}}+\varepsilon_{\mathrm{t}+\mathrm{h}-1}+\ldots \ldots \ldots \ldots+\varepsilon_{\mathrm{t}+1}$

Regression filter reduces to a difference filter when applied to a random walk. Hamilton suggested $\mathrm{h}=8$ for business cycles and $\mathrm{h}=20$ for studies in financial cycles. Regression $\mathrm{v}_{\mathrm{t}}$ converges in large samples to $\alpha_{1}=1$ and all other $\alpha_{\mathrm{j}}=0$. Thus, the forecast error is $\mathrm{v}_{\mathrm{t}+\mathrm{h}}=\mathrm{y}_{\mathrm{t}+\mathrm{h}}-\mathrm{y}_{\mathrm{t}}$.

The equation $\mathrm{v}_{\mathrm{t}}$ can be decomposed into trend, cycle and seasonally adjusted through SEAT/TRAMO or STL or census X-13 packages. Even it can be used for $\operatorname{ARIMA}(\mathrm{p}, \mathrm{d}, \mathrm{q})$ model for forecasting at date.(For yearly data $h=4$ and for monthly data $h=24$ are normally used).

Author has collected data from 1990-91 to 2018-19 on gross fiscal deficit and net state domestic product at current prices of Rajasthan from the Reserve Bank of India.

\section{OBSERVATIONS FROM ECONOMETRIC MODELS}

* Findings on gross fiscal deficit of Rajasthan

The pattern of gross fiscal deficit of Rajasthan from 1990-91 to $2018-19$ is not a linear trend.The non-linear trend line of the gross fiscal deficit in cubic form is estimated below.

$\log (x)=8.08959+0.5029 t-0.03175 t^{2}+0.00071 t^{3}+u_{i}$
$(22.06) *(4.83) *(-3.97) *(4.05)^{*}$

$\mathrm{R}^{2}=0.8718, \quad \mathrm{~F}=56.699 *, \mathrm{DW}=1.127, *=$ significant at $5 \%$ level, $\mathrm{n}=29, \mathrm{x}=$ gross fiscal deficit of Rajasthan in million Rupees, $\mathrm{t}=$ year.

This non-linear trend line is a good fit with high $\mathrm{R}^{2}$ and significant $\mathrm{F}$ and DW. The coefficients of $\mathrm{t}, \mathrm{t}^{2}, \mathrm{t}^{3}$ are also significant at $5 \%$ level. The trend line has been stepping upward, then it started to decline and thereafter it is increasing. Thus, the shape is inverse $\mathrm{S}$ type. It is seen in Figure 1.

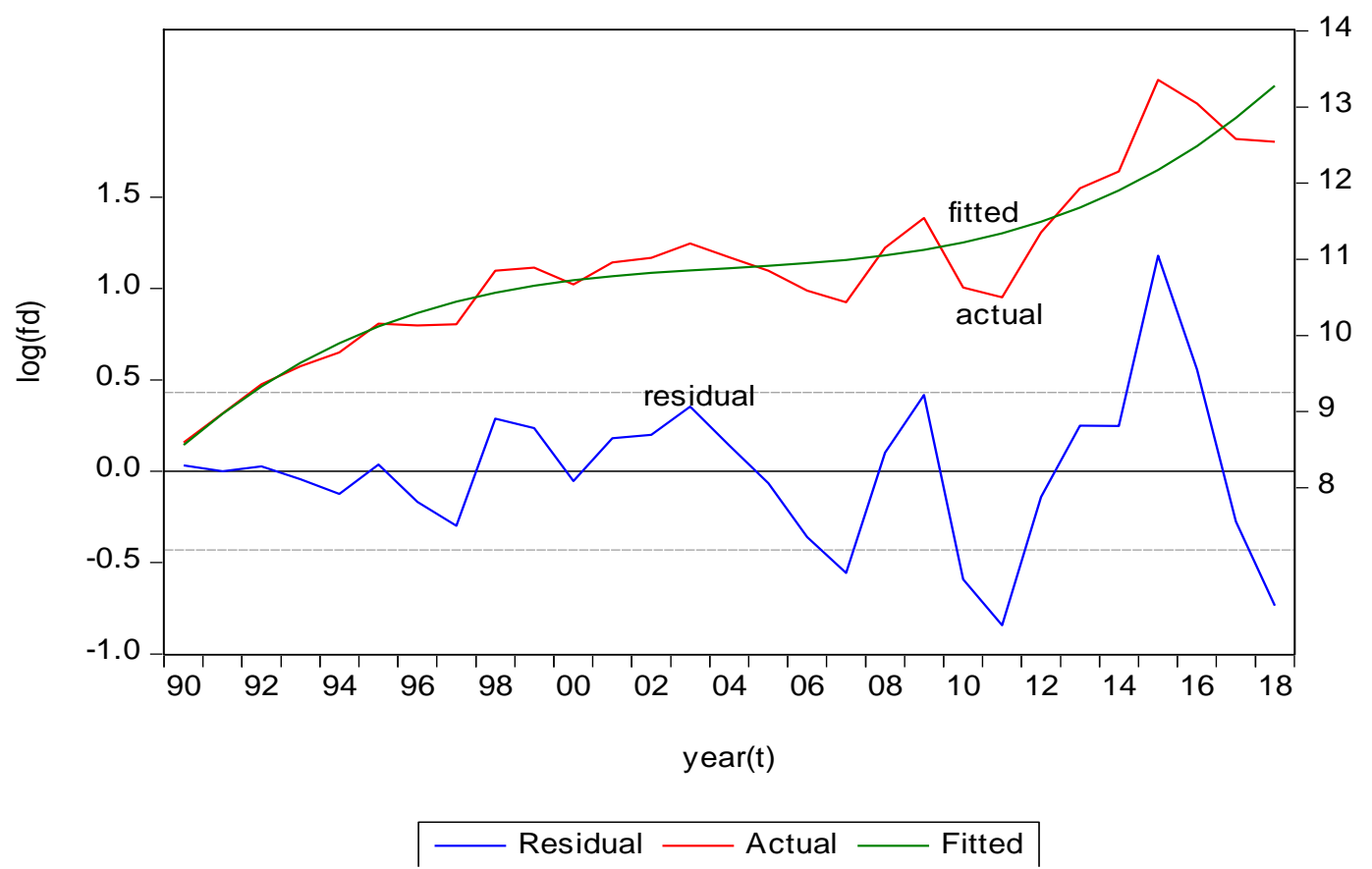

Fig 1:-The nonlinear trend of fiscal deficit

Source: Plotted by author

Using Cochrane-Orcutt(1949) forecasting least square model for 2030, it was found that the gross fiscal deficit has been increasing linearly at the rate of $10.44 \%$ per year significantly where $\ln (\mathrm{x})$ at $1990-91=8.594154$ and $\ln (\mathrm{x})$ at
$2030=13.706499, \quad$ and $\quad R^{2}=0.866, F=16.62, D W=1.63$ respectively. The forecast trend line has been rising steeply upward which is significant at 5\% level.In Figure 2,the actual and forecast lines have been clearly observed. 


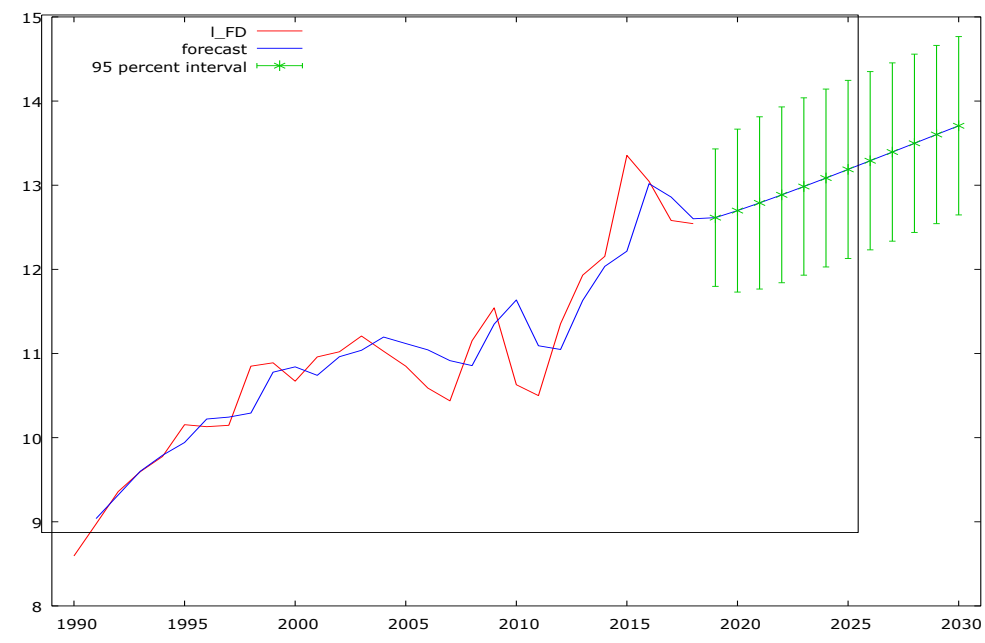

Fig 2:- Forecast of fiscal deficit for 2030 Source: Plotted by author

The gross fiscal deficit of Rajasthan from 1990-91 to 2018-19 showed three significant upward structural breaks in 1994,1998 and 2013 respectively which were found by applying Bai-Perron(2003)test of L+1 vs L sequentially determined breaks selecting trimming $=0.15$, HAC standard errors and covariance of the Bartlett kernel and Newey-West fixed bandwidth $=4.0$ respectively.In Table 1,the coefficients,its standard errors,t statistic and probabilities have been arranged neatly.

\begin{tabular}{|c|c|c|c|c|}
\hline Variable & Coefficient & Std. Error & t-Statistic & Prob. \\
\hline $\mathrm{C}$ & & $1990-1993-4 \mathrm{obs}$ & & 0.0000 \\
\hline $\mathrm{C}$ & 9.130784 & 0.188864 & 48.34571 & \\
\hline & & $1994-1997--4$ obs. & & \\
\hline $\mathrm{C}$ & 10.05174 & 0.064655 & 155.4662 & 0.0000 \\
\hline $\mathrm{C}$ & 10.91176 & $1998-2012--15$ obs. & & 0.0000 \\
\hline & & 0.052914 & 206.2159 & 0.0000 \\
\hline $\mathrm{R}^{2}=$ & $2013-2018--6$ obs. & & 72.39187 \\
\hline 0.9032 & $\mathrm{~F}=$ & 0.174075 & $\mathrm{AIC}=1.00250$ & $\mathrm{SC}=1.191093$ \\
\hline
\end{tabular}

Table 1:- Structural breaks of fiscal deficit Source: Calculated by author

In Figure 3,the actual and fitted lines with upward structural breaks in 1994,1998 and 2013 and the residuals have been depicted with marking.

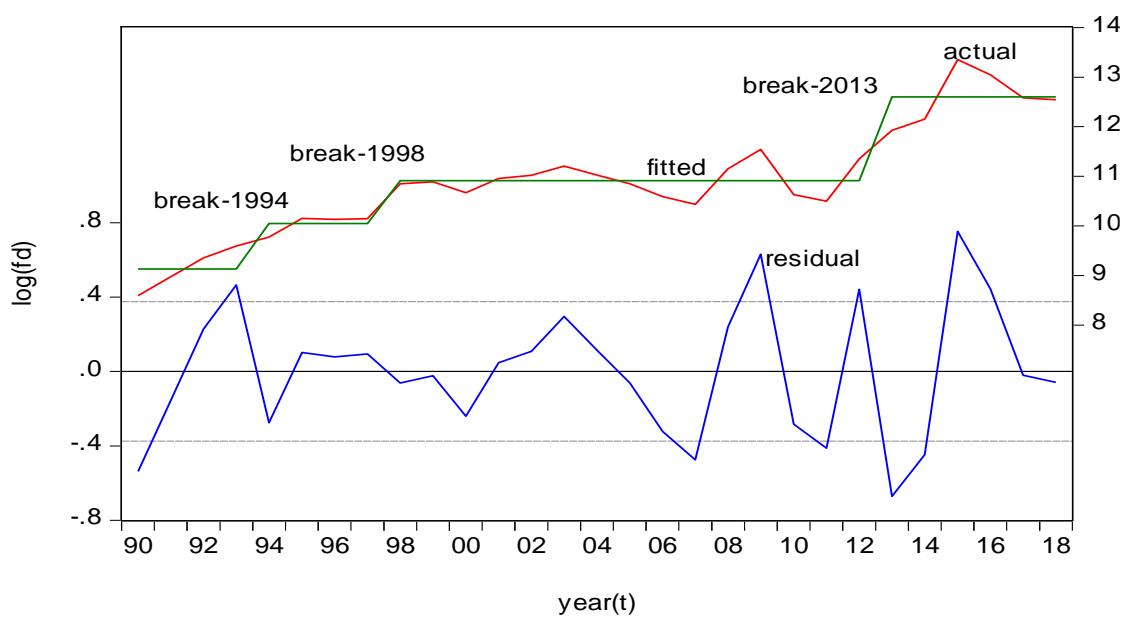

- Residual — Actual — Fitted

Fig 3:- Structural breaks of fiscal deficit

Source: Plotted by author 
The estimated decomposition of Hamilton (2018) regression filter of gross fiscal deficit of Rajasthan during 1990-91 -2018-19 is given below where the residual $\mathrm{v}_{\mathrm{t}}$ is the Hamilton cycle.

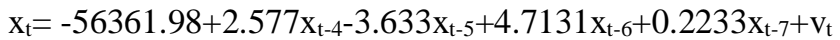
$(-0.87)(2.08)^{*} \quad(-1.77) \quad(2.19)^{*} \quad(0.13)$ $\mathrm{R}^{2}=0.47, \mathrm{~F}=3.81^{*}, \mathrm{AIC}=26.516, \mathrm{SC}=26.764, \mathrm{DW}=0.500$, $\mathrm{n}=22$, period $=1997-98-2018-19, *=$ significant at $5 \%$ level and $\mathrm{x}=$ gross fiscal deficit in million rupees of Rajasthan.

Thus, $\mathrm{v}_{\mathrm{t}}=\mathrm{x}_{\mathrm{t}}-\left[-56361.98+2.577 \mathrm{x}_{\mathrm{t}-4}-3.633 \mathrm{x}_{\mathrm{t}-5}+4.7131 \mathrm{x}_{\mathrm{t}-}\right.$ $\left.6+0.2233 \mathrm{x}_{\mathrm{t}-7}\right]$

In Figure 4, the panels of diagrams explained the nature of cycle, cyclical trend, seasonal variations, remainder and the seasonally adjusted cycle of the decomposition of Hamilton filter model which were found from the STL methodology. In panel1,the residual of Hamilton decomposition is plotted where the cycle consists of 6 peaks and 6 troughs in which the cycles take time of 2 years, 3 years and 6 years respectively. In panel 2,the smooth cyclical trend was found having one peak and trough in which recovery took five years and recession completed by ten years.In panel 3,the seasonal variation of fiscal deficit is inverse $\mathrm{v}$ shaped with equal amplitudes since the data is annual.In panel 4,the remainder consists of short cycles having seven peaks and six troughs respectively.In panel 5 , the seasonally adjusted cycle is similar with the residual of filter series.
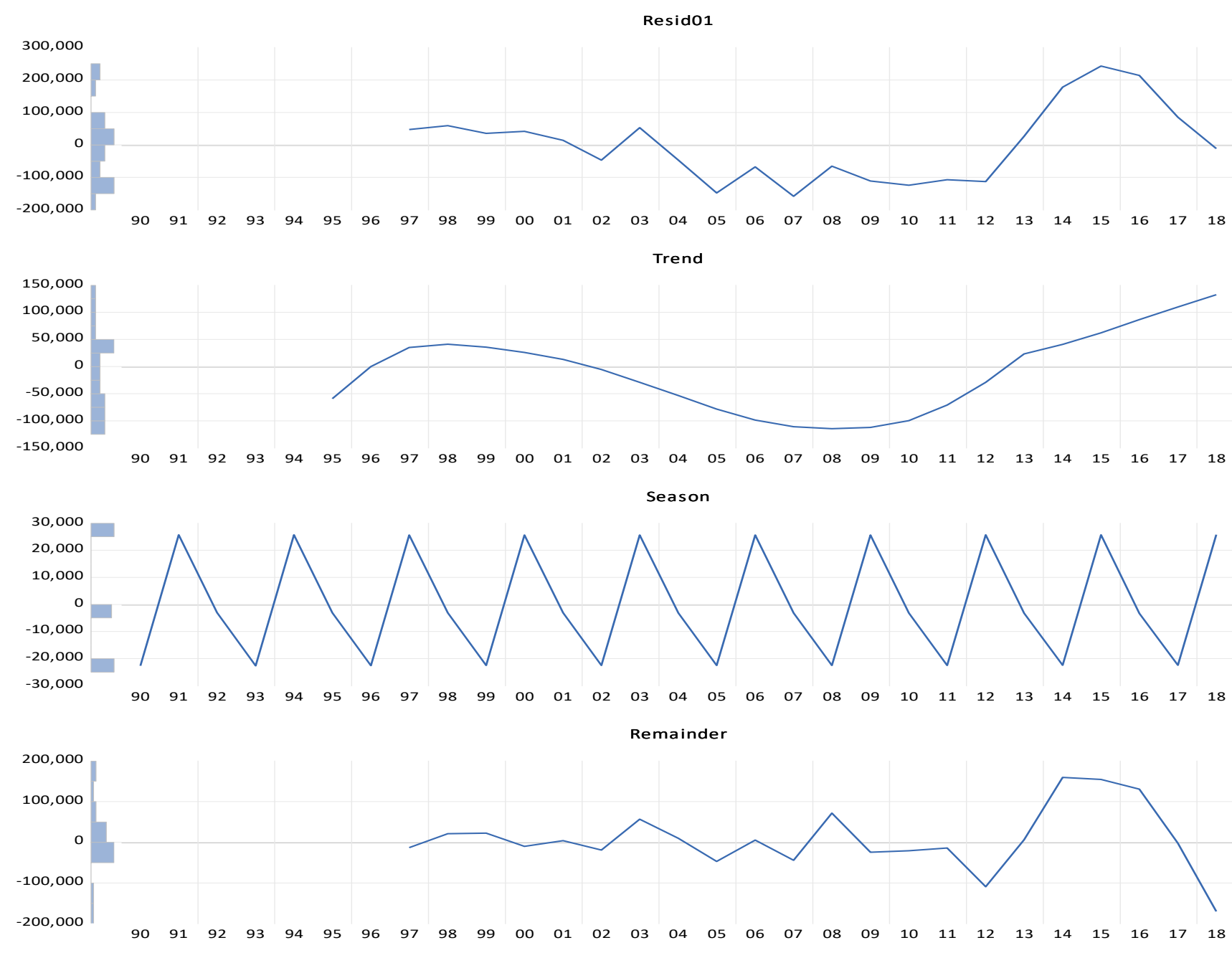

Adjusted

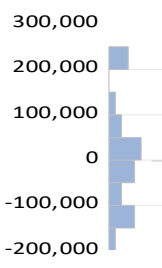

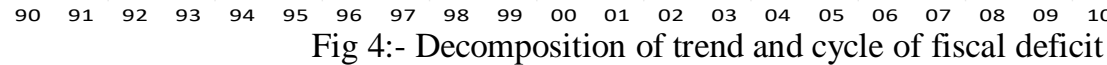

Source: Plotted by author. 
The seasonal variation of fiscal deficit in the decomposition can be verified through the autocorrelation and partial autocorrelation functions which are shown in Figure 5, where ACF is highest in lag one then it started to be negative at lag four and thereafter it is increasing up to lag nine and then started declining. On the other hand, the PACF is positive highest at lag one and then it is negative at lag two and started to fall and reached positive at lag five and then it fell negative and declined upto lag eight respectively. There is one spike in PACF. All the Q statistic are significant at 5\% level. In Figure 5, the values with shapes of ACF and PACF have been established.

\begin{tabular}{c|c|rrrrrr} 
Autocorrelation & \multicolumn{1}{c}{ Partial Correlation } & AC & PAC & Q-Stat & Prob \\
\hline \hline & & \\
\hline
\end{tabular}

Fig 5:- ACF and PACF of fiscal deficit Source- Plotted by author

Grouped figures of gross fiscal deficit of Rajasthan which have been obtained from the method of SEATS/TRAMO showed that a complete cycle is required 12 years as has been observed in the smooth cyclical trend where peak achieved at 1998-99 and then it reached trough at 2008-09 and afterwards it increases. So,the declining trend of fiscal deficit is very slow covering 9 to 10 years. The seasonally adjusted cycle and the residual cycle of fiscal deficit are similar with huge peaks and troughs of deficits in Rajasthan where the amplitude is highest in 2015-16.The seasonally adjusted forecast is inverse $\mathrm{v}$ shaped steadily marching around the equilibrium uniformly.

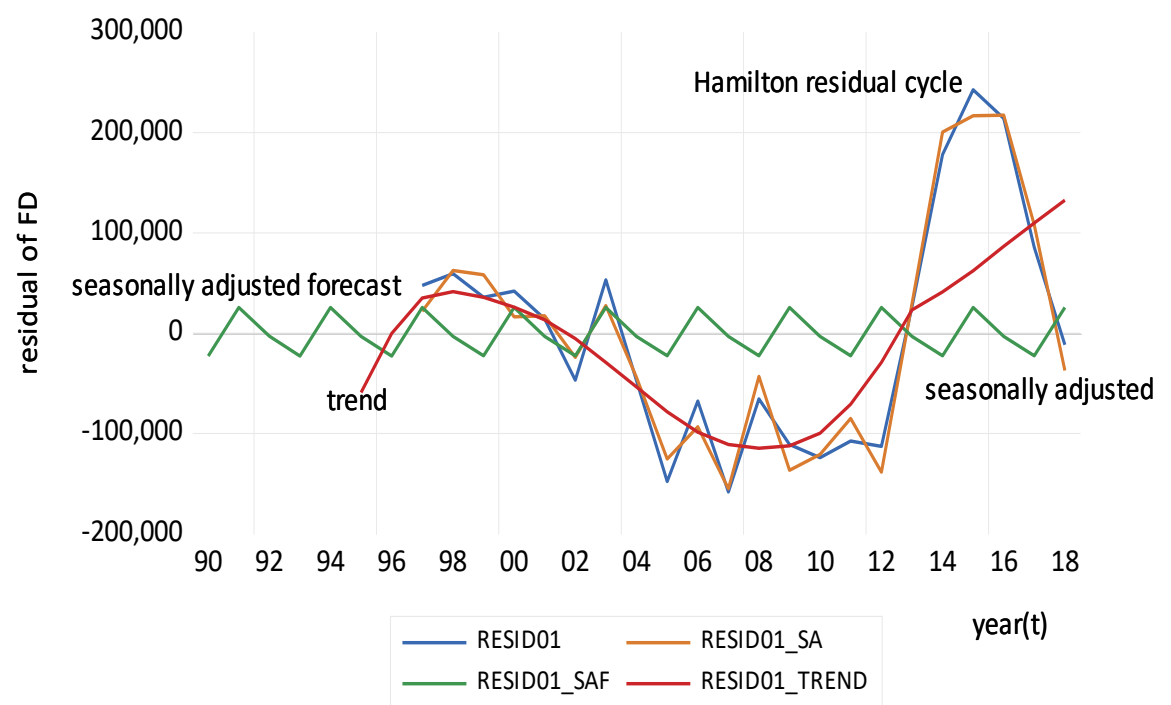

Fig 6:- Decomposition of gross fiscal deficit in a group Source:Plotted by author

Hamilton regression filter residual when passes through the forecasting ARIMA (p,d,q) model for 2030 has been fitted with ARIMA $(2,0,1)$ during the adjusted period 1997-98-2018-19 with 22 observations which was selected from 20 best models and found that the coefficient of $\mathrm{AR}(2)$ is significant at $6 \%$ level, coefficient of MA(1) is significant at $1 \%$ level, coefficient of $\sigma^{2}$ is significant at $1 \%$ level, $\mathrm{R}^{2}=0.599, \mathrm{~F}=8.97 *, \mathrm{DW}=1.80, \mathrm{AIC}=25.568$ which is minimum and $\mathrm{SC}=25.76$ respectively. The roots $\mathrm{AR}= \pm 0.69$ and root of $\mathrm{MA}=-0.91$, so that the model is stable,convergent,and stationary. The estimated model by maximum likelihood method is given below. 
$\mathrm{v}_{\mathrm{t}}=2828.542+0.4726 \mathrm{v}_{\mathrm{t}-2}+\varepsilon_{\mathrm{t}}+0.9079 \varepsilon_{\mathrm{t}-1}+4.89 \mathrm{E}+09 \sigma_{\mathrm{t}}^{2}$
$(0.0507)$
$(2.017)^{*}$
$(5.507)^{*}$
$(2.58)^{*}$

$(*=$ significant at $6 \%$ level $)$

In Figure 7,this $\operatorname{ARIMA}(2,0,1)$ of $\mathrm{v}_{\mathrm{t}}$ has been plotted in actual and predicted lines where the predicted line marches towards equilibrium non-linearly where the volatility is also minimized because the coefficient of $\sigma^{2}$ is significant. The predicted line from 2018-19 to 2030 has been marked by green vertical lines which lie within 5\% significant level but finally it did not reach at zero although it approaches towards zero.

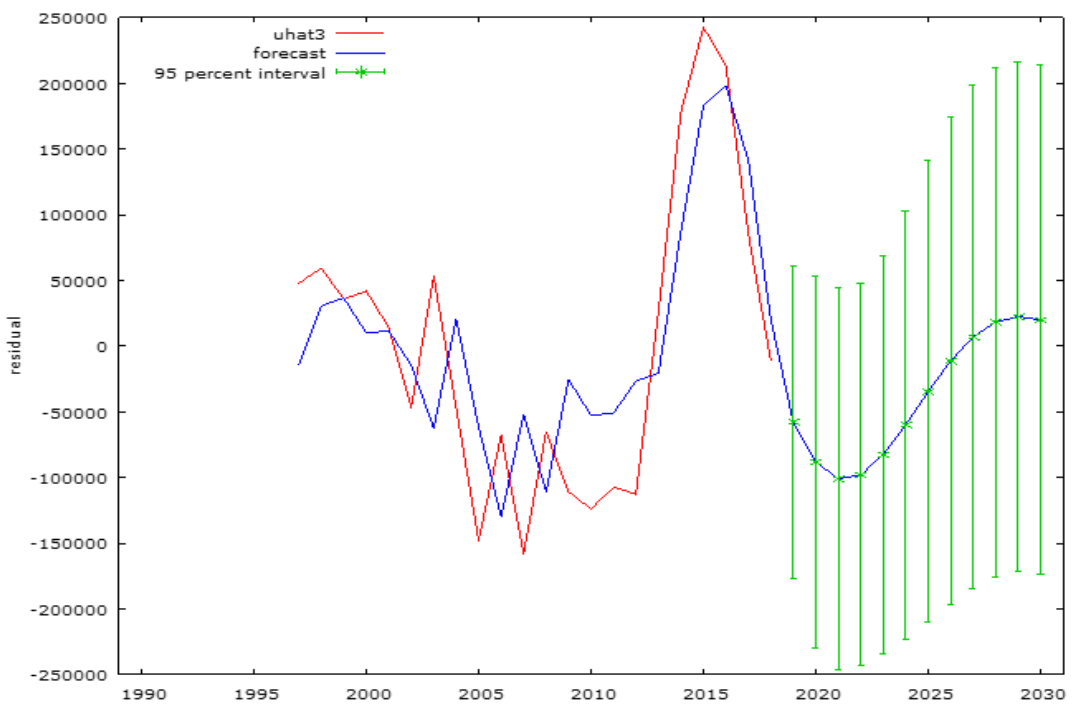

Fig 7:- Hamilton ARIMA(2,0,1) for 2030

Source-Plotted by author

This forecasting ARIMA $(2,0,1)$ model of residual of gross fiscal deficit of Rajasthan has no problem of heteroscedasticity because $\mathrm{nR}^{2}=1.014327$ whose probability of $\chi^{2}(2)=0.6022$ where $n=20, \mathrm{R}^{2}=0.050716$ which implies that $\mathrm{H} 0=$ no heteroscedasticity is accepted at null hypothesis. By applying $\mathrm{ARCH}(2)$ method of residual squares the estimated equation is given below.

$\varepsilon^{2}=4.71 \mathrm{E}+09+0.2195 \varepsilon^{2}{ }_{t-1}-0.10976 \varepsilon^{2}{ }_{t-2}+\check{e}_{t}$

$\mathrm{R}^{2}=0.0507, \mathrm{~F}=0.454, \mathrm{DW}=2.03, \mathrm{AIC}=47.98, \mathrm{SC}=48.13, *$ significant at $5 \%$ level

\section{* Findings on Fiscal deficit \% of NSDP of Rajasthan}

Gross Fiscal deficit of Rajasthan as percent of net state domestic product at current prices from 1990-1 to 2018-19 is a nonlinear pattern where the trend line has been increasing and then it started to decline and thereafter it is moving upward significantly.All the coefficients of $\mathrm{t}, \mathrm{t}^{2}$ and $\mathrm{t}^{3}$ are found significant at $5 \%$ level. Thus, the estimated nonlinear trend line is a good fit.

$\log (y)=0.6439+0.3686 t-0.0312 t^{2}+0.00068 t^{3}+u_{i}$

$$
(3.31)^{*}(-3.65)^{*}(3.657) *
$$

$\mathrm{R}^{2}=0.400, \mathrm{~F}=5.576^{*}, \mathrm{DW}=1.0735, \mathrm{n}=29,{ }^{*}=$ significant at $5 \%$ level, $\mathrm{y}=$ gross fiscal deficit of Rajasthan as per cent of net state domestic product at current prices, $\mathrm{t}=$ year.

In Figure 8,the nonlinear trend line of fiscal deficit as per cent of net state domestic product of Rajasthan looks like an inverse $\mathrm{S}$ type shown below. 
ISSN No:-2456-2165

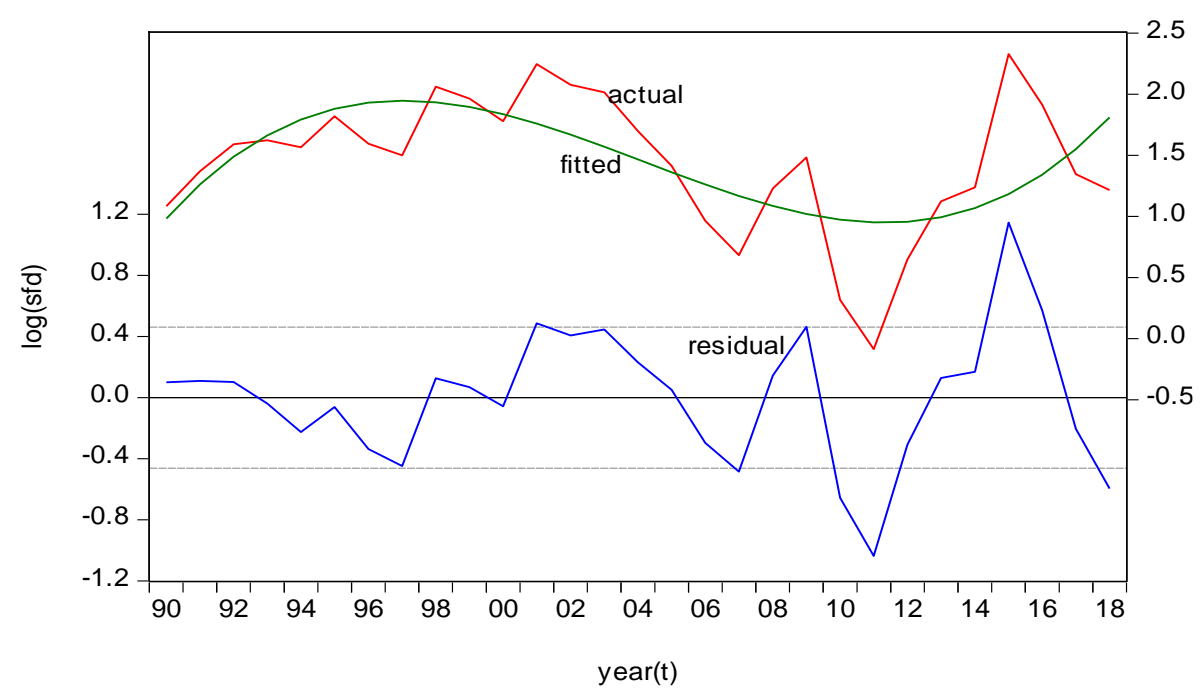

- Residual — Actual — Fitted

Fig 8:- Fiscal deficit \% of NSDP

Source: Plotted by author

Similarly,by using Cochrane-Orcutt(1949) forecasting least square model for 2030,it was found that the gross fiscal deficit as percent of net state domestic product of Rajasthan at current prices has been decreasing linearly at the rate of $3.12 \%$ per year insignificantly where $\ln (\mathrm{y})$ at $1990-91=1.082822$ and $\ln (\mathrm{y})$ at $2030=0.717384$ and $\mathrm{R}^{2}=0.0 .48, \mathrm{~F}=1.425, \mathrm{DW}=1.628$ respectively.The forecast trend line has been rising steeply downward which is significant at 5\% level.In Figure 9,the actual and forecast lines have been clearly observed.

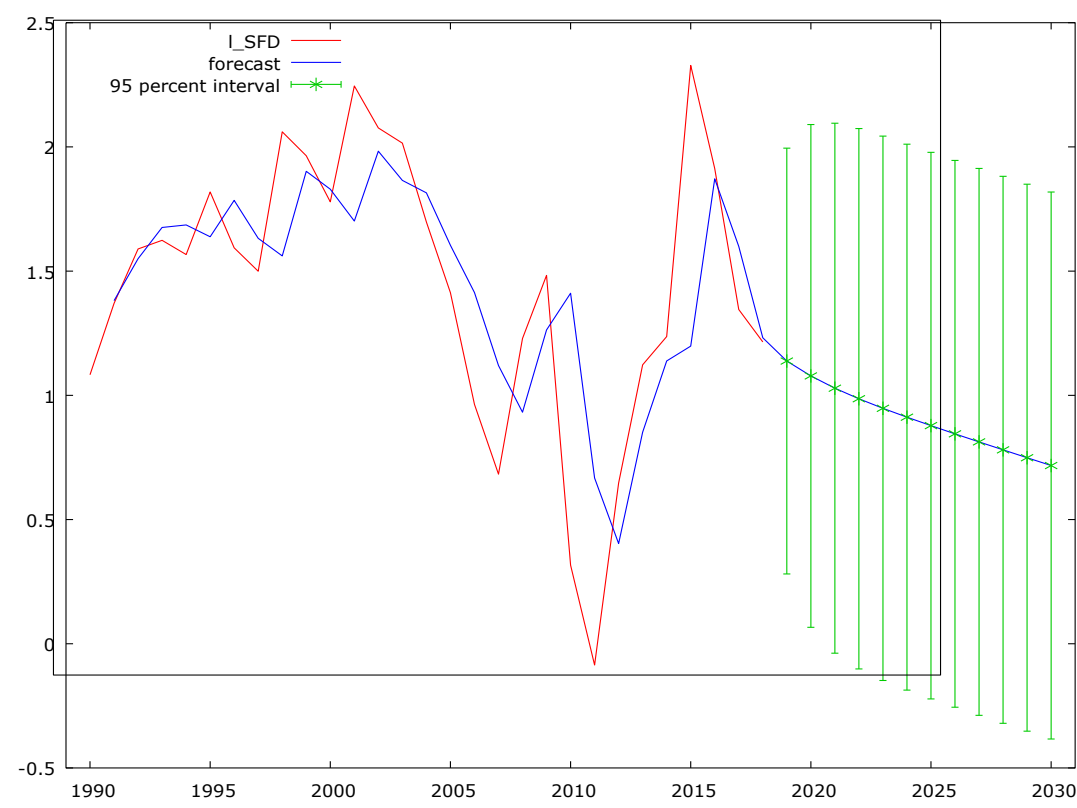

Fig 9:- Forecast of FD \% of NSDP of Rajasthan

Source: Plotted by author

Hamilton regression filter for the decomposition of trends and cycles of gross fiscal deficit as per cent of NSDP of Rajasthan at current prices during 1990-91-2018-19 have been estimated below.

$\mathrm{y}_{\mathrm{t}}=5.3815+0.33775 \mathrm{y}_{\mathrm{t}-4}-0.4841 \mathrm{y}_{\mathrm{t}-5}+0.4529 \mathrm{y}_{\mathrm{t}-6}-0.40399 \mathrm{y}_{\mathrm{t}-7}+\mathrm{v}_{\mathrm{t}}$
$(3.25)^{*}$
$(0.829) \quad(-0.953)$
$(0.892)$
$(-0.976)$

$\mathrm{R}^{2}=0.09108, \mathrm{~F}=0.425, \mathrm{AIC}=5.09, \mathrm{SC}=5.34, \mathrm{DW}=0.958, \mathrm{n}=22$,period=1997-98-2018-19 after $\quad$ adjustment, $*=$ significant $\quad$ at $5 \%$ level,y=gross fiscal deficit of Rajasthan at current prices as per centage of net sate domestic product at current prices of Rajasthan. 


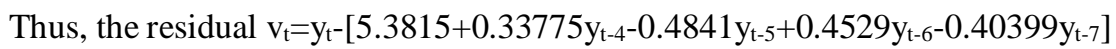

This $v_{t}$ is called Hamilton regression filter of gross fiscal deficit as per cent of NSDP of Rajasthan which constitutes patterns of cycles. This $\mathrm{v}_{\mathrm{t}}$ has been decomposed with cycles,cyclical trend,seasonal variation,remainder and seasonally adjusted cycle by applying STL method whose diagrammatic representations are shown in Figure 10 in various panels.In panel 1,the residual or gross fiscal deficit \% of NSDP has been depicted which consists of six peaks and five troughs where complete cycles were needed 2,3,4 years respectively with high amplitude in 2001-02 and 2015-16.In panel 2,the smooth cyclical trend clearly showed only one peak and trough in which recessionary trend took eleven years and recovery period was completed within six years.In panel 3 ,the seasonal variation is inverse $\mathrm{v}$ shaped with similar amplitudes.In panel 4,the remainder and in panel 5,the seasonally adjusted cycles were shown which are more or less similar with the residual cycle.
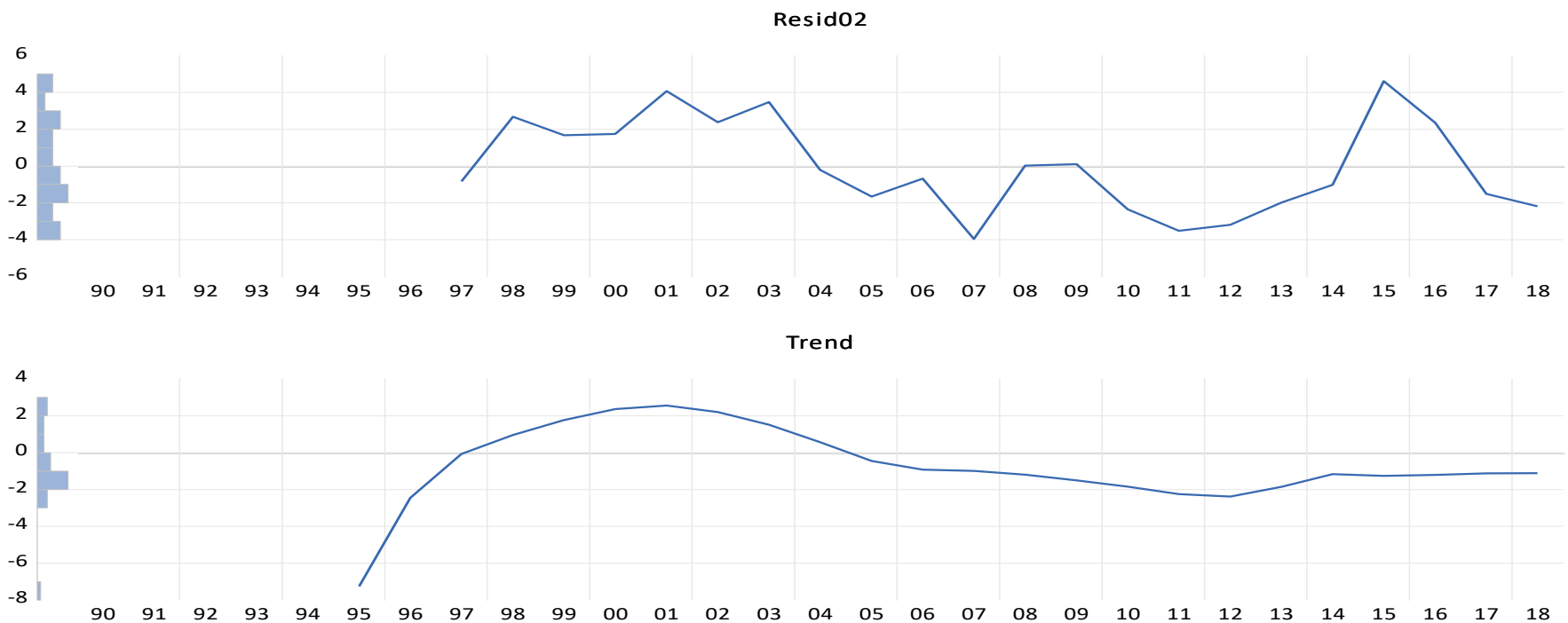

$\begin{array}{lllllllllllllll}90 & 91 & 92 & 93 & 94 & 95 & 96 & 97 & 98 & 99 & 00 & 01 & 02 & 03 & 04\end{array}$

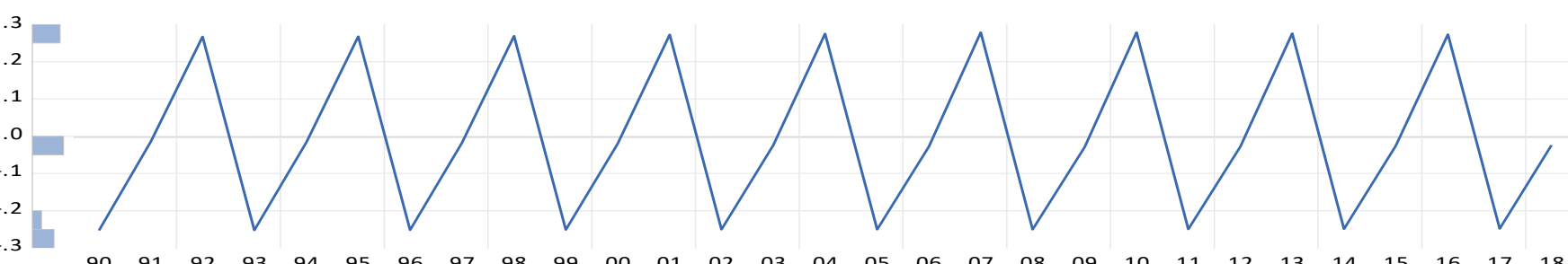

$\begin{array}{lllllllllllllllllllllllllllll}90 & 91 & 92 & 93 & 94 & 95 & 96 & 97 & 98 & 99 & 00 & 01 & 02 & 03 & 04 & 05 & 06 & 07 & 08 & 09 & 10 & 11 & 12 & 13 & 14 & 15 & 16 & 17 & 18\end{array}$

Remainder

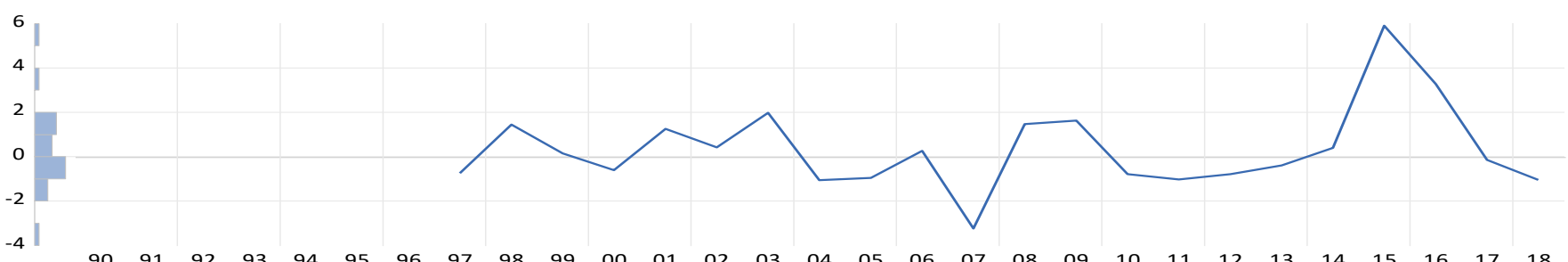

Adjusted

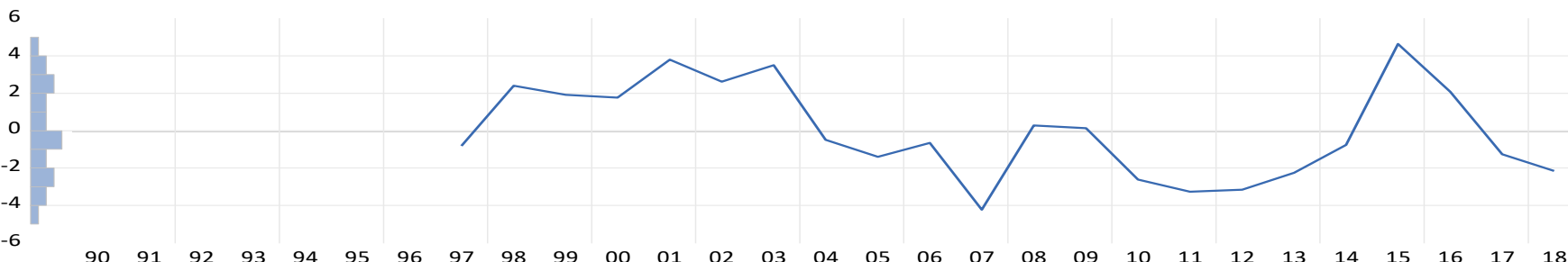

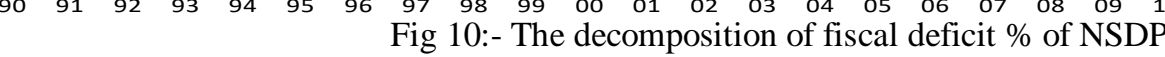

Source- Plotted by author. 
The seasonal fluctuations have been verified by the patterns of autocorrelation and partial autocorrelation functions of residual $\mathrm{v}_{\mathrm{t}}$ where ACF is positive highest in lag 1 and tends to negative till at lag 4 and then it tends to positive upto lag 7 thereafter it became negative which decreases gradually.PACF is positive highest at lag 1 then it started negative till lag 4 and again at lag 5 it is positive and then it tends to negative up to lag 12.There is only one spike in PACF.All Q statistic are significant at $5 \%$ level.In Figure 11, the ACF and PACF are shown vividly.

\begin{tabular}{|c|c|c|c|c|c|c|c|c|}
\hline Autocor & ation & Partial Co & Iation & & $A C$ & PAC & Q-Stat & Prob \\
\hline 1 & & 1 & & 1 & 0.501 & 0.501 & 6.2983 & 0.012 \\
\hline 1 & 1 & 무 & 1 & 2 & 0.164 & -0.115 & 7.0118 & 0.030 \\
\hline I & 1 & I & I & 3 & 0.016 & -0.024 & 7.0193 & 0.071 \\
\hline 미 & I & 미 & 1 & 4 & -0.111 & -0.123 & 7.3781 & 0.117 \\
\hline 1 & 1 & 1 & 1 & 5 & 0.006 & 0.169 & 7.3793 & 0.194 \\
\hline 1 & 1 & I & 1 & 6 & 0.003 & -0.090 & 7.3796 & 0.287 \\
\hline 1 & 1 & 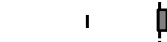 & 1 & 7 & 0.022 & 0.058 & 7.3965 & 0.389 \\
\hline $1 \square$ & 1 & $\square$ & 1 & 8 & -0.246 & -0.426 & 9.6853 & 0.288 \\
\hline $1 \square$ & 1 & 1 & 1 & 9 & -0.369 & -0.029 & 15.226 & 0.085 \\
\hline $1 \square$ & 1 & I & 1 & 10 & -0.242 & -0.026 & 17.806 & 0.058 \\
\hline $1 \square$ & 1 & 1 & 1 & 11 & -0.196 & -0.031 & 19.651 & 0.050 \\
\hline 1 d & 1 & 1 व & 1 & 12 & -0.066 & -0.084 & 19.878 & 0.069 \\
\hline
\end{tabular}

Fig 11:- ACF and PACF of fiscal deficit \% of NSDP Source-Plotted by author

In a grouped figure 12, the smooth cyclical trend of fiscal deficit as per cent of NSDP of Rajasthan has been speedily increasing at peak level then it is slowly fallingdownward trend which implies that fiscal deficit per cent of NSDP has been falling slowly and then increasing. The cycle and the seasonally adjusted cycle of fiscal deficit are similar with many short cycles although seasonally adjusted forecast is steadily regular towards equilibrium. The grouped figure was obtained from the method of SEATS/TRAMO.

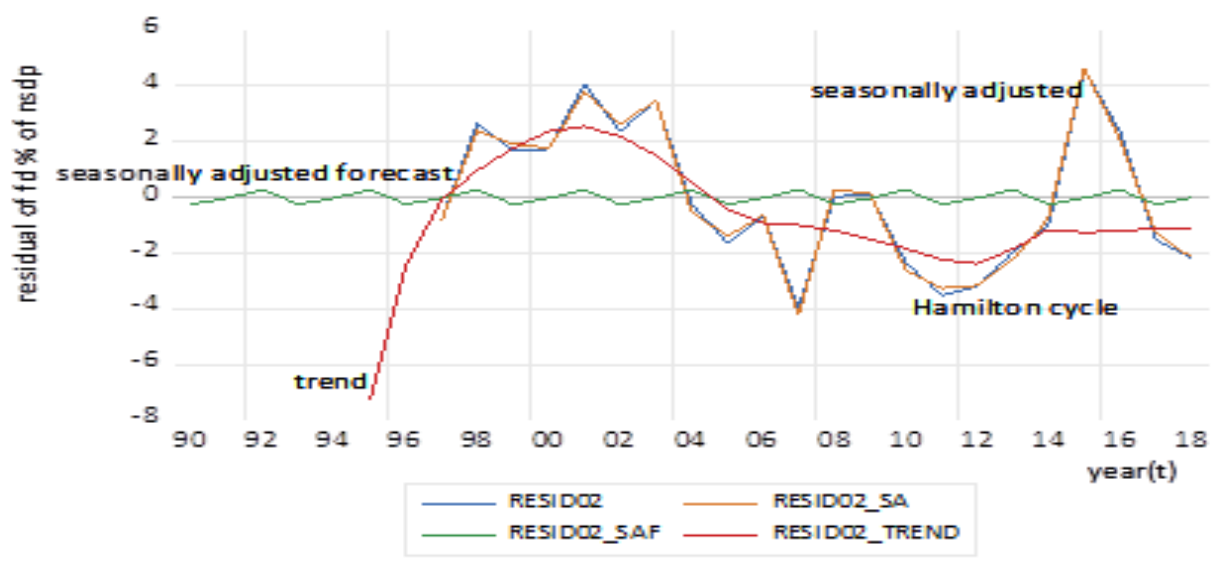

Fig 12:- Grouped figure of cycles in FD\%NSDP

Source-Plotted by author

Hamilton regression filter residual when passes through the forecasting ARIMA model for 2030 has been fitted with ARIMA(0,0,3) during the adjusted period 1997-98-2018-19 with 22 observations which was selected from 20 best models and found that coefficient of $\mathrm{MA}(3)$ is convergent but not significant at 5\% level, coefficient of $\sigma^{2}$ is significant at 5\% level, $\mathrm{R}^{2}=0.0003, \mathrm{~F}=0.0029, \mathrm{DW}=0.958, \mathrm{AIC}=4.916$ which is minimum and $\mathrm{SC}=5.064$ respectively. The roots of $\mathrm{MA}=-0.13 \pm 0.22 \mathrm{i}$, and -0.26 ,so that the model is stable,convergent, and non-stationary. The estimated model calculated by maximum likelihood method is given below.

$\mathrm{v}_{\mathrm{t}}=0.00151+\varepsilon_{\mathrm{t}}+0.01669 \varepsilon_{\mathrm{t}-3}+6.0828 \sigma_{\mathrm{t}}^{2}$

$(0.0027) \quad(0.0705) \quad(2.209)^{*}$

$(*=$ significant at $5 \%$ level)

In Figure 13,this ARIMA $(0,0,3)$ of $\mathrm{v}_{\mathrm{t}}$ has been plotted in actual and predicted lines where the predicted line marches towards equilibrium non-linearly where the volatility is also minimized because the coefficient of $\sigma^{2}$ is significant. The predicted line from 2018-19 to 2030 has been marked by green vertical lines which lie within 5\% significant level but finally it did not reach at zero. 


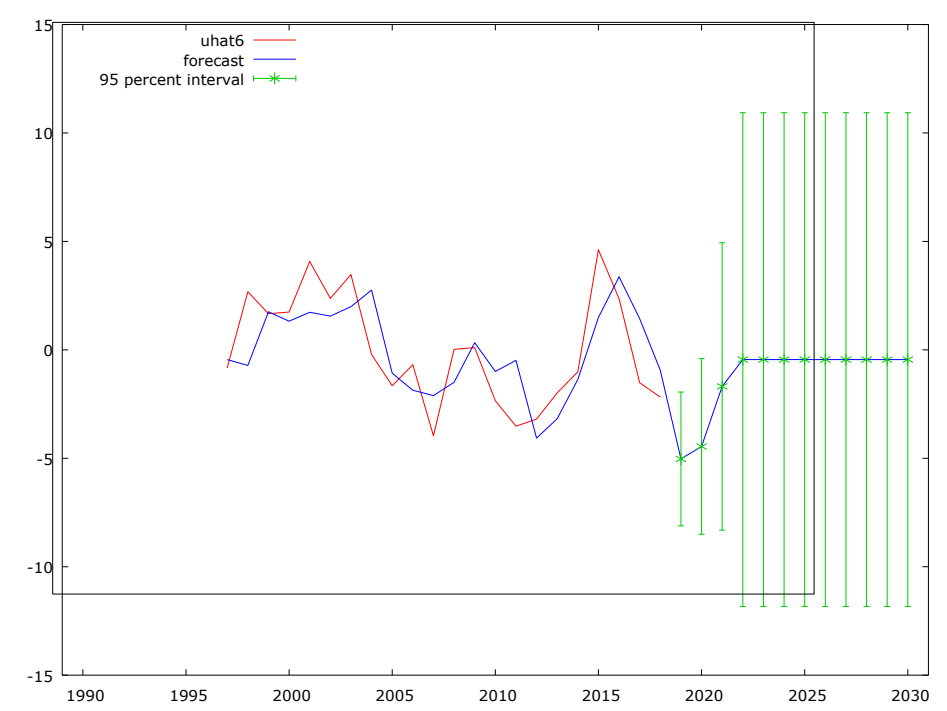

Fig 13:- Hamilton ARIMA(0,0,3) of fiscal deficit \% of NSDP for 2030 Source-Plotted by author

\section{LIMITATIONS AND FUTURE SCOPE OF RESEARCH}

The paper excluded the quarterly or monthly data of fiscal deficit of Rajasthan which prevented the good outcome of seasonal variations and ARMA structure. Even this paper expected additional observations of the variables so that decomposition analysis would be more reliable and perfect. The cointegration and vector error correction analysis are also excluded in this paper so that the determinants of fiscal deficit of Rajasthan were not discovered. Even, the trends and cyclical fluctuations could be easily compared with H.P.Filter or Kalman filter or Baxter and King filter models respectively. Therefore, there remain huge scopes for future research in those areas of fiscal deficit of Rajasthan.

\section{POLICY ISSUES}

Gross fiscal deficit of Rajasthan is observed as structural and procyclical during the cyclical pattern from 1990-91-2018-19 and even in smooth cyclical trend. It is predicted that NSDP has been stepping up more than $10 \%$ per year up to 2030 so that if Rajasthan government is able to keep up the unemployment rate with in the range of $5 \%$ per annum, then the anticyclical fiscal policy will be helpful for the long run measure along with sustainable development goals.

\section{CONCLUSIONS}

The paper concludes that the trend line of gross fiscal deficit of Rajasthan from 1990-91to 2018-19 is nonlinear which is upward followed by downward and then started upswing like an inverse S shape.The linear trend for 2030 showed that it has been stepping up at the rate of $10.44 \%$ per year significantly.Gross fiscal deficit has three upward structural breaks in 1994,1998 and 2013 respectively.Hamilton regression filter of gross fiscal deficit of Rajasthan consists of six peaks and troughs in the cyclical patterns but in the smooth cyclical trend there is only one peak and trough and there are inverse $\mathrm{V}$ shaped seasonal variations with uniform amplitudes.ARIMA $(2,0,3)$ model has been passed through Hamilton filter in gross fiscal deficit for 2030 which was found convergent and stationary showing no heteroscedasticity problem. Similarly, the trend line of gross fiscal deficit as per cent of net state domestic product of Rajasthan is also non-linear which is upswing followed by downswing and then it was upward but the linear trend line for 2030 stated that it has been declining at the rate of $3.12 \%$ per year during 1990-91-2018-19 significantly. It has no structural breaks. The cycle of Hamilton regression filter has clearly six peaks and five troughs and the smooth cyclical trend showed only one peak and trough but the seasonal variations are inverse $\mathrm{v}$ shaped with equal amplitudes. ARIMA $(0,0,3)$ forecast model for 2030 has been fitted with Hamilton filter which was found significant, convergent but nonstationary process although it was approaching towards equilibrium.

\section{REFERENCES}

[1]. Adam, C. S.,\& Bevan,D.L. (2005). Fiscal Deficits and Growth in Developing Countries. Journal of Public Economics, 89, 57197.https://econpapers.repec.org/RePEc:eee:pubeco:v:8 9:y:2005:i:4:p:571-597

[2]. Anantha Ramu,M.R.,\& Gayithri,K.(2016).Relationship between fiscal deficit composition and economic growth in India:A Time Series econometric analysis.(Working Paper -367, Bangalore: The Institute for Social and Economic Change).https://mpra.ub.uni-muenchen.de/76304/

[3]. Bai,Jushan., \&Perron, P.(2003). Critical values for Multiple Structural Change Tests.Econometrics Journal, 6,72-

78.https://econpapers.repec.org/RePEc:ect:emjrnl:v:6: y:2003:i:1:p:72-78 
[4]. Box, George., \& Jenkins, Gwilym. (1976). Time Series Analysis, Forecasting and Control. San Francisco: Holden Day. https://www.abebooks.com/firstedition/Time-Series-Analysis-Forecasting-ControlHolden-Day/3057095791/bd

[5]. Centre for Budget and Governance Accountability.(2011). RAJASTHAN:Tracking Public Investments for Children Budgeting for Change Series. http://www.cbgaindia.org/wpcontent/uploads/2011/04/Rajasthan.pdf

[6]. Cleveland, R.B., Cleveland, W.S., McRac, J.E., \& Terpenning, L.(1990).STL: A Seasonal Trend Decomposition Procedure Based on Loess. Journal of Official Statistics,6(1),3-33. https://www.wessa.net/download/stl.pdf

[7]. Cochrane,D., \& Orcutt,G.H.(1949).Application of Least Squares Regression of Relationships containing Autocorrelated Error Terms.Journal of the American Statistical Association, 44(245),32-61. https://en.wikipedia.org/wiki/Cochrane\%E2\%80\%93 Orcutt_estimation.

[8]. Hamilton, J. D. (2018). Why you should never use the Hodrick Prescott Filter. Review of Economics and Statistics, 100(5),831-

84, https://econweb.ucsd.edu/ jhamilto/hp.pdf.

[9]. Kaur,Gurleen.(2017-2018,April-March).The relationship between fiscal deficit and inflation in India:A Cointegration Analysis.Journal of Business Thought, 8,24-41 http://www.informaticsjournals.com/index.php/jbt/arti cle/download/21195/17415.

[10]. Mundle, Sudipto., Bhanumurthy, N.R., \& Das, Surajit.(2011).Fiscal consolidation with high growth: A policy simulation model for India. Economic Modelling, Elsevier, 28(6),26572668. https://ideas.repec.org/a/eee/ecmode/v28y2011i6 p2657-2668.html.

[11]. PTI.(2020,February 20).Budget 2020-21 'Nirogi Rajasthan' farmer welfare top priorities for Rajasthan govt.https://www.theweek.in/wire-

updates/business/2020/02/20/des24-rj-2ndld\%20 budget.html

[12]. Rajaraman,Indira.,Mathur,O.P.,\&

Majumder,Debdatta.(2005). Final Report on Restructuring State and Local Finances for Rajasthan.New Delhi:National Institute of Public Finance and Policy.https://www.nipfp.org.in/media/medialibrary/20 13/08/Rajasthan_complete.pdf

[13]. Segal,Paul.,\& Sen,Anupam.(2011,August).Oil Revenues and Economic Development:The Case of Rajasthan,India.Oxford University of Energy Studies.WPM-43.

https://www.oxfordenergy.org/wpcms/wpcontent/uploads/2011/08/WPM-43.pdf

[14]. Singh,Surjit., $\&$ Mahamallik,Motilal.(2014,November). Evaluation Of State Finances: A Study Of Rajasthan.Jaipur: Institute of Development Studies, https://fincomindia.nic.in/writereaddata/html_en_files/ oldcommission_html/fincom14/others/21.pdf
[15]. Taylor, L et al.(2012). Fiscal Deficits, Economic Growth and Government Debt in the USA. Cambridge Journal of Economics, 36 (1),189-204. https://www.researchgate.net/publication/227464545_ Fiscal_deficits_economic_growth_and_government_d ebt_in_the_USA 